\title{
Manpower Training and Development in Nigeria Public Organisations: A Study of Abia State Civil Service.
}

\author{
Anikwe Sunday Obinna (PhD) \\ Department of Industrial Relations and Personnel Management \\ Micheal Okpara University of Agriculture, Umudike, Umuahia, Abia State
}

\begin{abstract}
Every organization is established for a purpose. The purpose of any organization is being achieved by man who is the source of existence of the organization. Hence, the necessity for staff training and development. Manpower training and development seeks to improve the performance of work units, departments, and the whole organization. It looks in depth at where an organization stands in comparison to where it hopes to be in the future, and develops the skills and resources to get there. The ultimate goal of staff training and development is to enable the organization to grow stronger in achieving its purpose and mission. The general objective of this study is to examine how staff training and development enhance organizational effectiveness in Abia State civil service. The specific objectives are to examine if there is any significant relationship between manpower training and development of employees and employee productivity level in Abia State Civil Service, and to ascertain the problems of manpower training and development in Abia State civil Service. The findings of the study revealed that investment in training in Abia state civil service was seen to improve its financial standing, increase employee knowledge and expertise and also enhance service delivery.
\end{abstract}

Keywords: Manpower, Manpower Training, Manpower Development, productivity, employee performance.

\section{Introduction}

Manpower training and development is essential to the success and productivity of every organization. Although technology and the internet have enabled global collaboration and competition, employees are still the organization's competitive advantage. Manpower training and development enables employees to develop skills and competence necessary to enhance bottom-line results for their organizations.

Every organization is established for a purpose. The purpose of any organization is being achieved by man who is the source of existence of the organization. Hence, the necessity for staff training and development. Manpower training and development seeks to improve the performance of work units, departments, and the whole organization. It looks in depth at where an organization stands in comparison to where it hopes to be in the future, and develops the skills and resources to get there. The ultimate goal of staff training and development is to enable the organization to grow stronger in achieving its purpose and mission.

Training and development both encompasses the process of improving the effectiveness of organizations and their employees. Training has been defined by scholars as an activity related to immediate changes in organizational effectiveness through giving organised instruction, while development is associated to achieving longer-term organisational and employee goals. Training and development have been given differing definitions by management scholars, though the two are most times used together or interchangeably (Aguinis \& Kraiger, 2009).

Training refers to a systematic process that involves an activity where employees are educated on matters of technical knowledge that are related to their jobs. It concentrates on teaching employees how to use different machineries to increase efficiency in the workplace. Training both physically, socially, intellectually and 
mentally is very essential in facilitating not only the level of productivity but also the development of personnel in organizations. Therefore, training can be put in a context relevant to school administrators. However, knowledge is the ability, the skill, the understanding, the information, which every individual requires in order to be able to function effectively and perform efficiently.

Abiodun (2000) submitted that training is a systematic development of the knowledge, skills and attitudes required by employees to perform adequately on a given task or job. It can take place in a number of ways, on the job or off the job; in the organization or outside the organization. Wayne (2005) observed that training involves making use of planned programmes which are specifically programed to enhance performance at all organizational levels.

On the other hand, defining manpower development can be problematic particularly if an international perspective is taken because its interpretation and roles tend to vary from one country to another. However, manpower development involves the overall holistic and educational growth and maturity of people in managerial positions. It is a continuous process developed in order to guarantee the development of employee competencies, dynamism, motivation and effectiveness in a more organised manner. Manpower development process generally focuses on organized series of learning activities geared towards producing behavioural changes in human resources in order to enable them acquire desired level of competence to meet their job challenges (Mahapatro, 2010). This process of manpower development is always discussed in relation to attitudes, adaptability, leadership and human relations in the organisation.

The recognition that human resources are value means for improving productivity as the most valuable assets of any organization since the management of other resources (e.g. information resources, material resources etc.) entirely depends on it, this study was based on how those assets could be developed. The importance of training and development is very crucial given the growing complexity of the work environment, the rapid change in organizations and advancement in technology, among other things. Training and development helps to ensure that organizational members possess the knowledge and skills they need to perform their jobs effectively, take on new responsibilities and adapt to changing conditions.

Civil service in Nigeria is bedevilled with inefficiency and inability of employees to effectively perform their duties in order to enhance productivity. Low service delivery, corruption, low productivity, among other problems negatively influence the civil service in Nigeria. These problems might not be far from lack of qualified and skilled employees, and hence the need for this study.

The significance of this research lies in its contribution to the literatures on human resource training and development. This work would largely complement our broad based knowledge on the nature, functions, objectives and character of manpower resources training and development. In other words, it would serve as a primary source of data to readers and researchers.

Theoretically, the research would also stimulate future readers in the task of complementing the work already done. For this reason, the study will add to the body of knowledge and as well aid the organizations in understanding the abysmal conditions shrouding most human resources training and development policies. It is hoped that, apart from the work enriching existing literatures on human resources training and development, it will be of immense benefit to future researchers and scholars in the quest for additional knowledge. At the practical level, it will serve as a guide to practioners in the field of human resource management especially in the formulation of policies on manpower training and development.

\section{Problem Statement}

In Nigeria, inefficiency is a very serious problem that needs to be addressed urgently. Europe faced this same problem in the $18^{\text {th }}$ and $19^{\text {th }}$ centuries and writers such as Max Weber (1947), Vroom (1970), and a host of others were able to address the issue of how organizations can increase output and improve efficiency.

Most organizations find it difficult to identify the training needs, and even where the need is recognized, a lot of time and money is committed to staff training and development. The exercise is often either inappropriate, haphazard or premised on a faulty diagnosis of organizational training needs. In other situations, where training happens to occur, deployment of staff so trained may be without regard to the skill 
the staff acquired, leading to frustration of personnel so trained and also general inefficiency in the system. Public enterprises in Nigeria are fond of this practise (Onah, 2013). The workforce is generally undertapped, under-utilized and therefore falls short of its anticipated contributions to the realization of organizational goals. It is appalling to note that mangers in Nigeria have paid little or no attention on staff training programmes often manifest tripartite problems of incompetence, inefficiency and ineffectiveness. Numerous scholars have been writing on how efficiency, competence and effectiveness can be achieved through training.

Oguntimehin (2001) and some other notable scholars highlighted the usefulness of training and identified the functions of training as follows; increase productivity, improves the quality of work, improves skills, knowledge, understanding and attitude; enhance the use of tools and machine; reduces waste, accidents, turnover, lateness, absenteeism and other overhead costs, eliminates obsolesce in skills, technologies, methods, products, capital management etc. It brings incumbents to that level of performance which needs the performance for the job; enhance the implementation of new policies and regulations; prepares people for achievement, improves man-power development and ensures the survival and growth of the enterprise.

However, in light of the above expositions, the following questions were posited to guide the study;

(i) Is there any significant relationship between manpower training and development and their employee productivity level in Abia State Civil Service?

(ii) What presages the problems of manpower training and development in Abia State Civil Service?

\section{Study Objectives}

The general objective is to examine how staff training and development enhance organizational effectiveness.

The specific objectives are to:

(i) Examine if there is any significant relationship between manpower training and development of employees and employee productivity level in Abia State Civil Service.

(ii) Ascertain the problems of manpower training and development in Abia State civil Service.

\section{Operationalization of Key Concepts}

There are certain terms which are central to the discussion and analysis of the issues raised. It is therefore necessary that these concepts be classified particularly with regards to their usage in the discussion and consequently, how they are to be comprehended in the study. They include:

Staff: This refers to the human resources available in an organization that will deal with planning, decisions, and execution of the functions that will inform the significance of the existence of the organization.

Training: Training can be seen as the formal procedure which an organization uses to facilitate employees learning so that their resultant behavior contributes to the attainment of the organizations as well as the individuals' goals and objectives.

Development: This means an over-all shift from an existing state of affairs to a totally new dispensation. Development means the acquisition of a higher status production and distribution of skills that result in high efficiency and productivity.

Manpower: Total supply of personnel available or engaged for a specific job or task. It is the supply of people who are able to work or who are needed to do a particular job.

\section{Literature Review}

In order to evaluate and clarify the related works of other scholars, especially as relates to this work and also to establish a fundamental basis for this research work, the related literatures were reviewed under the following sub-themes:

\section{The Concept of Manpower Training}


Training is a process that develops and improves skills related to performance. Effective training programmes, according to Blum and Naylor (1976), can result in increased productivity, reduced labour turnover, and greater employer satisfaction. Also, training refers to the processes involved in the teaching and learning activities embarked upon for the sole purpose of helping employees acquire the necessary knowledge, skills, abilities and attitudes needed by their organisation. In other words, it involves the act of helping to enhance the knowledge and skills of employees for doing a particular job (Mahapatro, 2010).

According to Abiodun (1999), training is a systematic development of the knowledge, skills and attitudes required by employees to perform adequately on a given task or job. Employees who have not received adequate training before being assigned with responsibilities lack the necessary confidence with which to carry out the job. An employee should be helped to grow into more responsibility by systematic training and development. McGehee and Thayer (1961) see training as the formal procedures which an organization use to facilitate employees' learning so that their resultant behaviour contributes to the attainment of the organizations as well as the individual's goals and objectives. Training involves making use of planned programs specifically designed to enhance the performance of employees at the individual, group, and/or organizational levels. Improved performance, in turn, means that there was significant improvement in employee's knowledge, skills, attitudes, and/or social behaviour (Cascio, 2010).

Furthermore, training according to Nwachukwu (1988) is an organizational effort aimed at helping an employee to acquire basic skills required for the efficient execution of the functions for which he was hired or employed. On the other hand, he regards development as the activities undertaken to expose an employee to perform an additional duties and assume positions of importance in the organizational hierarchy. Training as it is observed exposes employees to skills necessary for effective job performance while development goes further to equip employees with the knowledge required for performing additional responsibility to a particular task faster and better than before, development may involve exposing an employee to more challenging task.

Cole (2002) defined training as any learning activity which is directed towards the acquisition of specific knowledge and skill for the purposes of an occupation or task. He contends that the focus of training is the job or task. However, he sees development as any learning activity which is directed towards future needs rather than present needs and which is concerned more with career growth than immediate performance. He further goes on to state that the focus of development tends to be primarily on an organization future manpower requirements and secondly, on the growth needs of individuals in the workplace.

Armstrong (2003) posits that training is the formal and systematic modification of behavior through learning which occurs as a result of education instruction, development and planned experience. This, Drucker (1984) agreed in his definition of training as a systematic process of altering the behavior and/or attitudes of employees in a direction to increase organizational goals.

Consequently, analyzing the above definitions, one can say that both training and development result in creating a change in an individual. Thus, there is a kind of similarity between training and development because both concepts are aimed at creating a favourable change in the individual. Employee training and development complement each other in an organization's quest to evolve qualified manpower. This is the reason why most authors use the terms "training and development" as synonyms. It is common for people to use training and development interchangeably as if both are the same whereas; there is a distinction between the two. Though differ in concept but can be studied together because of their relatedness and mutual effect on the staff.

In any event, we will in this work study the two concepts together because they produce the same effect on the staff, which is the improvement of work effectiveness and efficiency. The purpose of training and development has been identified to include; creating a pool of readily available and adequate replacements for personnel who may leave or move up in the Organization; enhancing the company's ability to adopt and use advances in technology because of a sufficiently knowledgeable staff; building a more efficient, effective and highly motivated team, which enhances the company's competitive position and improves employee morale; help the organization achieve its purpose by adding value to its key resources-the people it employed and ensuring adequate human resources for expansion into new programs. In other words, 
training refers to the teaching and learning activities carried on for the primary purpose of helping members of an organization acquire and apply the knowledge, skills, abilities and attitudes needed by that organization. Broadly speaking, training is the act of increasing the knowledge and skills of an employee for doing a particular job.

\section{Manpower Development Defined}

Lots of time training is confused with development, both are different in certain respects yet components of the same system. Development implies opportunities created to help employees grow. It is more of long term or futuristic in nature as opposed to training, which focus on the current job. It also is not limited to the job avenues in the current organisation but may focus on other development aspects also.

Manpower development, commonly referred to as Human Resource Development (HRD) can be regarded as the basis for helping employees develop their personal and organizational skills, knowledge, and abilities. Manpower development involve some activities such as employee training, employee career development, performance management and development, coaching, mentoring, succession planning, key employee identification, tuition assistance, and organization development.

At most organizations, for example, employees are expected to mandatorily attend training program on presentation skills however they are also free to choose a course on 'perspectives in leadership through literature'. Whereas the presentation skills program helps them on job, the literature based program may or may not help them directly.

Similarly, many organisations choose certain employees preferentially for programs to develop them for future positions. This is done on the basis of existing attitude, skills and abilities, knowledge and performance of the employee. Most of the leadership programs tend to be of this nature with a vision of creating and nurturing leaders for tomorrow.

The major difference between training and development therefore is that while training focuses often on the current employee needs or competency gaps, development concerns itself with preparing people for future assignments and responsibilities.

Development focuses on building the knowledge and skills of organizational members so that they will be prepared to take on new responsibilities and challenges. In the view of Adamolekun (1983), staff development involves the training, education and career development of staff members. The purpose of training and development has been identified to include: creating a pool of readily available and adequate replacements for personnel who may leave or move up in the organization; enhancing the company's ability to adopt and use advances in technology because of a sufficiently knowledgeable staff; building a more efficient, effective and highly motivated team, which enhances the company's competitive position and improves employee morale; and ensuring adequate human resources for expansion into new programs.

The purpose of manpower development is to improve knowledge and skills and to change attitude (Mullins, 1999). Mullins argues further that manpower development is capable of producing the following benefits:

- Increase the confidence, motivation and commitment of staff;

- Provide recognition, enhanced responsibility, and the possibility of increased pay and promotion;

- Give feeling of personal satisfaction and achievement, and broaden opportunities for career progression; and

- Help to improve the availability and quality of staff.

Training facilitates manpower development and consequently his performance. Manpower training and manpower development are two inter-related processes whose importance cannot be overemphasized in any decision of strategic human resource management. They are related through series of activities, which an enterprise would embark upon to improve the quality of its managerial capacity.

In the view of Chanokan (1987), manpower development refers broadly to the nature and direction of change induced in the employees as a result of educating and training programmes. He says that 
development is managerial in nature and career focused. To distinguish training and development, Chanokan has this to say, "that unlike the training, the workers which improves technical and mechanical skills, development techniques are designed for work behaviour modification". According to him, development is an educational process, utilizing a systematic organizational procedure by which a worker learns the conceptual and theoretical knowledge for effective pursuance of their responsibilities.

\section{Procedures in Organizing Manpower Training and Development Prograamme.}

The steps, stages, tools and methods for manpower development in organizations differs, and it is largely determined by the objectives of organizations, the idiosyncrasy of management staff or the chief executive, the organizational policy, as well as the organizational environment to mention a few. Thus, it is a common feature to see methods for manpower development varying from one organization to the other, just as a given organization can be tailored at adopting different methods at different times or a combination of techniques at the same time.

However, some methods for manpower development are stated below:

i. Orientation: This method of manpower development could be said to be an integral part of the recruitment exercise in that once an employee has been found appointable, it is expected that such an employee need to be positively oriented in line with the vision and aspiration of the organization for effective discharge of function. And since employee function in an organization is basically affected by his perception of the organization vis-à-vis the rules and principles that exist in the organization.

It therefore follows that an employee undergoes formal and informal orientation in a place of work. While the formal orientation focuses on job specification and occupational demands placed on the employee, the informal orientation involve the social interaction that take place in the place of work which could either boost productivity or be detrimental to it (Koontz et al., 1980). Orientation therefore, as a method of manpower development is quite indispensable because it helps in boosting the productivity of workers which is needed for competing in the global market of the 21 st century.

\section{ii. On the Job Method of Manpower Development:}

This method is basically different from the orientation method in that while orientation is at the point of entry into the organization or a new assignment; on the job method is a process through which knowledge and experience are acquired over a period of time either formally or informally. This process involve the following:

(a) Coaching: This is a method of on the job training and development in which a young employee is attached to a senior employee with the purpose of acquiring knowledge and experience needed for the performance of tasks. (Yalokwu 2000).

(b) Job Rotation: This method either involve the movement of an employee from one official assignment or department to the other, in order for the employee to be acquainted with the different aspects of the work process or through job enlargement. That is given additional responsibility to an employee who has been uplifted as a result of the acquisition of additional skill or knowledge (Yalokwu 2000; Lawal 2006).

(c) In House Training: This involve a formal method of on the job training in which skills and knowledge are acquired by employees through internally organized seminars and workshops geared toward updating the workers with new techniques or skills associated with the performance of their jobs. (Lawal 2006).

(d) In Service Training: This method involve training outside the organization or workplace in higher institution of learning or vocational centres under the sponsorship of the organization or on terms that may be agreed upon between the organization and the worker (Lawal 2006).

3. Committee/Work Group Method: This method entails manpower development through the involvement of employees in meetings, committees and work group discussion geared towards injecting inputs in form of decision making as regard solving organizational problem. This method is quite indispensable, especially in the aspect of training employees for managerial functions or heading organizational units. 
4. Vestibule Training Method: This is a method of manpower development through the acquisition of skills in a related working environment (Nongo 2005). Under this method the trainee practices his skill with identical equipment that he uses or he is expected to use in his actual place of work. This method is most suitable for sensitive operations where maximal perfection is expected. The purpose is therefore to enable perfection at work place.

5. Apprenticeship Method: This method of manpower development involve the acquisition of skill through extensive practice for over a period of time by the trainee. This type of manpower development device could either be formal or informal. In the informal environments the trainee is attached to the trainer, and he/she is expected to pay for an agreed period of apprenticeship (Nongo 2005). In the formal environment on the other hand, an employee of an organization could be placed under apprenticeship in the organization with pay.

\subsection{Research Procedure}

\section{Research Design}

This study utilized the descriptive research design. According to Burns and Grove (2003), descriptive research "is designed to provide a picture of a situation as it naturally happens". For the purpose of this study, descriptive research design was used to obtain salient information on manpower training and development in Nigeria public organisations.

\section{Sources and Method of Data Collection}

For the purpose of generating data for this study, we made use of documentary sources which is also known as 'Secondary Sources'. By documentary sources, we mean any written material (whether hand-written, typed or printed) that is already in existence, which was produced for some other purpose than the benefit of the investigator (Nwana cited in Obasi, 1999). In other words, the researcher mainly made use of secondary sources of data generation for the purpose of this study.

The sources of data for this study include official documents from the office of the Head of Abia State Civil Service, electronic documents from Abia State Government Website, etc. Also, the researcher extensively made use of relevant data derived mostly from journals, magazines, periodicals, newspapers, textbooks, seminar and conference papers.

The researcher opted to the use of secondary data because it helped in using the work of others to broaden the base from which scientific generalizations can be made. It also helped to improve the understanding of the problem being studied and provided a basis for comparison for the data that is collected by the researcher.

\section{Method of Data Presentation and Analysis}

The study adopted qualitative descriptive analysis which is an aspect of content analysis. According to Asika (2006:118), "qualitative descriptive analysis essentially has to do with summarizing the data generated in the research." Being a non-experimental research, the use of qualitative descriptive analysis was employed to analyze and present the data generated from our sources. This we will do through a careful analysis of the hypotheses with the data generated from the reviewed literature.

\section{Findings And Discussion}

\subsection{Findings and Discussion}

A thematic approach was employed in the presentation of the findings and discussion of this work. Here, the researcher extensively discussed the findings of this work as its relates to the research questions and objectives of this work. The findings of this study were carefully presented under the following subheadings:

$>$ The relationship between training and development and the productivity level of the employees of Abia State Civil Service.

The problems of employee training and development in Abia State Civil Service.

(i) The relationship between training and development and the productivity level of the employees of Abia State Civil Service. 
Abia State civil service reaps the reward of providing training for their employees as it is believed that welltrained workers help increase productivity and profits. Investing in employee training should improve worker retention rates, customer satisfaction and creativity for new product ideas. The following summarizes the relationship between training and development and the productivity of employees in Abia state civil service;

Training and Development Saves Time and Costs: Investment in training in Abia state civil service was seen to improve its financial standing. Poor performance often results when employees don't know exactly what functions they are supposed to perform, how to do their jobs or why they need to work in a specific manner. Training helps solve these performance problems by explaining the details of the job. This in turn reduces duplication of effort in the service and the time spent correcting mistakes. Improved performance from employee training in Abia state civil service reduces staff turnover, lower maintenance costs by reducing equipment breakdowns and result in fewer complaints from the people. Better performance from employees typically creates less need for supervision and brings increased worker output in the service.

Employee Satisfaction: Job satisfaction generally is believed to increase self-esteem among the employees and it improves when employees have a better understand of the workings of the organisation. Training in Abia state civil service enhanced the morale of the employees on the job and it increased their loyalty to the service. This is because employees that believe their organisation offers excellent training opportunities are generally less likely to leave their jobs within a year of training than employees with poor training opportunities.

Expectations and Needs: Training plays a key role in employee commitment, especially in the civil service. This was achieved because the training program were designed to meet expectations and needs of the employees. are more likely to retain employees who view their training as relevant to their jobs and subsequently have a positive commitment to their company. A successful training program consists of management providing employees with accurate information and communication about the training as well as a program that ensures that training is relevant to their jobs.

Turnover Costs: Keeping well-trained employees pays off significantly for Abia state civil service because the cost of employee turnover can be high. Costs include separation costs, such as exit interviews, administrative functions related to termination, severance pay and unemployment compensation. Replacement costs consist of attracting applicants, entrance interviews, testing, travel and moving expenses, pre-employment administrative expenses, medical exams and employment information. A study by the University of Wisconsin found that 75 percent of the demand for new employees was related to replacing workers who left the company.

(ii) The Problems of Employee Training and Development in Abia State Civil Service.

There are a lot of problems facing manpower training and development in Abia State civil Service and they include:

Inability to Evaluate Training Programmes: The civil service employee training initiatives do not produce needed results because they fail to evaluate their training programmes. Training evaluation involves a systematic process to ascertain whether employee training programs are effective and efficient. Organisations use training evaluation to assess if the employee training programs are aligned with the its goals and objectives. Training evaluation is very important in public organisations as it helps with the discovery of training gaps and opportunities in effective training employees. It collects information that can help determine improvements on training programs and help trainers decide if certain programs should be withdrawn. The training evaluation process is essential to assess training effectiveness, help improve overall work quality, and boost employee morale and motivation by engaging them in the development of training programs.

Technological Innovations. Introduction of technology innovations most times involve some changes in the administration of any organisation. With the proliferation of technology, the job of employee training in the service took on a new light, and also began to include the field of employee data maintenance, electronic 
data storage, etc. No longer was employee training a simple job that could be performed by random trainers. As employee training shifted to the use of electronic means, it became more and more difficult. The service administration found themselves tasked with increasingly complex tasks, which involves the constant use of hardware and software resources to train employees. It poses a problem, more than it provides a solution where the service employees lack the necessary and required training to effectively handle the robust employee data and information that are always on the increase in an organisation. Employee training will not be successful without proper organisation of employee data and records on previous training undertaken.

Lack of Training Needs Assessment: This is the process to identify gaps between current performance and department/organizational objectives. Training Needs Analysis (TNA) is the process in which an organisation identifies training and development needs of its employees so that they can perform effectively. It involves a complete analysis of training needs required at various levels of the organisation. This is an assessment that looks at employee and organizational knowledges, skills, and abilities, to identify any gaps or areas of need. Technology is changing at a very fast pace and so are the training and development needs of employees. Training needs assessment in Abia State civil service is most times done haphazardly thereby making the training process not to produce desired results. Also, it is often disregarded by the civil service for reasons such as time constraints or lack of perceived value by the service management. However, skipping the TNA can mean that time and money may be wasted on training that is unnecessary or ineffective.

Resource Inadequacy: Success in employee training and development largely depends on the magnitude of resource investments in the training process. Inadequacy of resources needed for training and development hampers the effectiveness of employee training in the service. The civil service encounters lack of adequate resources needed for effective training of its employees. These resources include financial resources, physical resources, human resources, etc. The government do not provide enough resources to the civil for training of employees. The civil also lack training centers that can accommodate large number of employees from the civil service.

Poor Records Management: This has caused serious impediments in several aspects of the public sector, especially in Abia State public service. This has negatively affected prompt payments and employment practices, delay in training and development of employees, revamping of government functions and organizational structures, strengthening of financial management and the national legal and regulatory framework of the service. In the absence of a culture of good records management, monitoring and evaluation, employee training and development cannot succeed as a well-kept record provide the basis for all these, which also endanger the quality of service delivery. It is imperative, therefore, for the service employees to adopt good record management practices, since this will support effective, transparent and accountable employee training and development. Accessible and reliable information will show what decisions were made as regards to employee training, actions taken, people who were involved and the rights and responsibilities that exist. It encourages organisations to make decisions on which employees or group of employees that should receive training, and what kind of training they should receive.

\section{Conclusion}

The importance of training and development is very crucial given the growing complexity of the work environment, the rapid change in organizations and advancement in technology, among other things. Training and development helps to ensure that organizational members possess the knowledge and skills they need to perform their jobs effectively, take on new responsibilities and adapt to changing conditions. The problems of employee training and development in Abia state civil service can be mitigated by the government providing adequate resources for employee training and development. The civil service should make necessary effort to evaluate training programmes so as to identify its strengths and weaknesses.

\section{References}

1. Abiodun, E.J.A. (2000) Human Resources Management; An Overview. Shomolu, Lagos: Concept Publication. 
2. Adamolekun, L. (1983), Public Administration: A Nigerian and Comparative Perspective. London: Longman.

3. Aguinis, H. \& Kraiger, K. (2009) Benefits of Training and Development for Individuals and Teams, Organizations, and Society. Annual Review of Psychology 60(1):451-74.

4. Armstrong, M. (2003) A handbook of Human Resources Management Practice. London: Koganpage Company.

5. Blum, M. and Naylor, J. (2006), Industrial Psychology. New York: Harper \& Row Boston: MCGraw-Hill. Cases from selected countries. Onitsha: Abbot Books Ltd.

6. Cascio, W., F.(2010) Managing human resources: productivity, quality of work life, profits (8th Ed). New York: McGraw-Hill/Irwin.

7. Cole, G.A. (2002) Personnel and Human Resource Management. London: Biddle Limited

8. Drucker, A.D. (1984). Managing for Result. New York: Harper and Row publishers.

9. Koontz et al (1980), Management. Japan: McGraw-Hill Publishing Company.

10. Lawal, M.M. (2006), Human resource Management: A Hand Book for Personnel Managers and Students of Administration. Abuja: Roots Books and Journals Nigeria Limited.

11. Mahapatro, B. B. (2010). Human Resource Management. New Delhi: New Age International (P) Ltd., Publishers.

12. McGehee, Y. and Thayer, P.W. (2001), Training in Business and Industry. New York: John Wiley and Sons.

13. Mullins, L.J. (1999) Management and Organizational Behavior. Prentice Hall: London.

14. Nongo, S. (2005) Fundalmental of Management. Makurdi: Aboki Publishing Company.

15. Nwachukwu, C.C. (1988) Management: Theory and Practice. Onitsha: Africana-FEP Publishers.

16. Onah, Fab. O. (2013), Human Resource Management (3rd Edition). Enugu: John Jacob's Classic Publishers Ltd.

17. Vroom, V.H. (1970) Motivation in Management. American Foundation for Management Research, New York.

18. Wayne, C., F. (2005) Managing Human Resources. (8th Edition). New York: McGraw Hill Inc.

19. Weber, M. (1947) Theory of Social and Economic Organization. New York: The Free Press.

20. Yalokwu, P.O. (2000), Management: Concept and Techniques. Lagos:Peak Publishers. 